\title{
The Effects of Expenditures for Labour Market Policy on Unemployment Rate
}

\section{Laura Južnik Rołar}

Faculty of Business, Management and Informatics Novo mesto, University of Novo Mesto, Novo Mesto, Slovenia

\section{Abstract}

Background: Labour market policy aims to fight against unemployment and to raise employment. With this study we attempt to contribute to the evidence of the effectiveness of active labour market policy. Objectives: In the empirical part of the paper we aim to research the relations between the labour market policies and macroeconomic variables. Methods/Approach: In order to distinguish the effects of expenditures for labour market policies on unemployment rate, we separately analysed the effects of expenditures for active labour market policies and the effects of expenditures for passive labour market policies on unemployment rate using panel regression analysis. Results: The expenditures for active labour market policies have negative and statistically significant effect on unemployment rate, whereas the expenditures for passive labour market policies have positive and statistically significant effect on unemployment rate. Conclusions: Not only the activation strategies with benefit conditioning, but also encouraging and enabling unemployed person to actively approach in searching for a job should be implemented. The implementation of activation strategies which create favourable conditions for unemployed people to develop their skills, fulfil their potential, continuously maintain contacts with the employers and actively participate in the society should be supported.

Keywords: labour market policies, effectiveness, microeconometric estimation, macroeconometric estimation, labour market, unemployment rate, European Union

JEL classification: C21, J64, J68

Paper type: Research article

Received: Dec 21, 2017

Accepted: Jan 13, 2018

Citation: Južnik Rotar, L. (2018), "The Effects of Expenditures for Labour Market Policy on Unemployment Rate", Business Systems Research, Vol. 9, No. 1, pp. 55-64.

DOI: 10.2478/bsrj-2018-0005

\section{Introduction}

Since 2008, the EU-27 has experienced the consequences of the most severe economic crisis: over 23 million unemployed with small and medium sized enterprises weakened by economic downturn. To strengthen the future growth and competitiveness the Europe 2020 strategy has been put in place. The Europe 2020 strategy addresses the main societal challenges and gives directions for smart, sustainable and inclusive growth. One of the greatest challenges is how to fight 
against the rising unemployment rates. According to the Eurostat unemployment report (Eurostat, 2017) from the beginning of 2005 until the first quarter 2008 the trend was declining unemployment rate which stood at $6.8 \%$ or 16.2 million persons. From that period on the unemployment rate reached $9.7 \%$, whereas from 2013 there is a trend of decreasing unemployment rate. At the end of 2016 the unemployment rate reached $8.2 \%$ (Eurostat, 2017).

In dealing with the rising unemployment rates and social exclusion, an important role is played by the labour market policies that can contribute to an increase in employment and a decrease in unemployment. Since there are large funds intended for the labour market policies, and since there is an increasing pressure in terms of budget limitations, an ageing population and other obstacles, the question of estimation of impacts of such policies and programmes is quite appropriate. The evaluation of the effectiveness of labour market policies and programmes is usually based on the use of different techniques which consider an individual's participation in an employment programme and assess the probability of future employment in comparison with the situation where the individual is not included in the programme. Such evaluations are part of microeconometric evidence of the impact of the labour market policies and programmes on different outcomes. Whereas macroeconometric evidence of the impact of the labour market policies and programmes focuses on the evaluation of the impact of such policies and programmes on macroeconomic variables (for example employment and unemployment). This approach typically relies on the cross-country econometric analysis based on panel data sets. Nevertheless, such evaluations can serve as a basis for the development and monitoring of economic effects of policies on the labour market. Secondly, the findings of such evaluations can serve as the professional basis for the economic policy makers. Thirdly, such evaluations contribute to the more effective distribution of funds.

Labour market policy aims to fight against unemployment and to raise employment. With this study, we attempt to contribute to the evidence of the effectiveness of active labour market policy. We follow the design of an aggregate impact analysis, which aims to explain the impact of labour market policies and programmes on macroeconomic variables. Therefore, the objective of our study is to estimate the effects of expenditures for labour market policies on unemployment rate. The objective of empirical study is to separately estimate the effects of expenditures for active as well as passive labour market policies on unemployment rate as there is a variety of programmes and measures within labour market policies and as such impact differently on unemployment rate. The hypothesis of the research is that the effects of expenditures for active labour market policies will be negative on unemployment rate, whereas the effects of expenditures for passive labour market policies will be positive on unemployment rate and as such not resulting in lowering the unemployment rate.

The structure of the paper is as follows. In the second section, we provide literature review focusing on the microeconometric and macroeconometric evidence of the impact of the labour market policies and programmes on different outcomes. We continue with the explanation of the methodology, whereas the fourth section comprises results of the estimations and their discussion. The final section concludes.

\section{Literature review}

There is a growing interest to estimate the effectiveness of active labour market policy especially in the context of evidence-based policy making which is the orientation of the European Commission in the programming period 2014-2020. 
Impact evaluations which are part of a broader agenda of evidence-based policy making can be described by a shift in focus from inputs to outcomes and results (Gertler et al., 2016). According to Gertler et al. (2016) impact evaluations can provide robust and credible evidence on performance and most importantly whether a particular programme has achieved its outcomes. This information is crucial also for decision makers, which decide whether a particular programme should continue or should it be terminated. Not only for decision makers also for citizens it is important whether public funds have been spent effectively.

In carrying out effective impact evaluations there is major challenge connected with such evaluations. That is to identify the causal relationship between programme or policy and outcomes of interest. From a microeconometric point of view, research focuses on the impact of particular programme or policy on participants in such programmes or policy. In an attempt to identify causal effects for such research one is inevitably faced with the fact that we cannot observe the same individual in two different situations simultaneously (see, for example Dehejia, 2013; Caliendo et al., 2015; Frölich et al., 2015). If we are trying to estimate the effectiveness of a certain employment programme this would mean that we are trying to compare the outcome of an individual participating in such employment programme with an outcome had that individual not participated in such employment programme (Južnik Rotar, 2012). Because we cannot observe the same individual in two different situations at the same time, the identification of causal effects is actually the problem of missing data (see, for example Rosenbaum et al., 1983; Khandker et al., 2010). Namely, the researcher is interested in the result that would occur if a person participates in the employment programme and on the other hand the result for the same person in the case of not participating in the employment programme - the so-called counterfactual (see, for example Hansen et al., 2014; Heckman et al., 2015; Huber et al., 2013).

On the other hand, from a macroeconometric point of view studies focus on general economic factors connected with the labour market, such as employment and unemployment rate (Gonzalez Carreras et al., 2015). The estimation of macroeconomic impact of active labour market policies on different factors associated with the labour market is typically implemented with panel data econometric approach (Martin, 2014).

Kluve (2010) estimates the effectiveness of European active labour market programmes based on meta-analysis and concludes that the employment programme type is almost exclusively the one that matters for programme effectiveness and not so much the other factors of economic expansion and contraction or public employment service as a typical labour market institution. Kluve (2010) found out that direct employment programmes in the public sector frequently not provide positive effects, while supports to employers to hire workers proved to be effective, whereas different programmes to equip participants with different knowledge and competences showed modest positive effects.

Card et al. (2015) based on using regression models for the estimated employment programme effects found out that in the short run the average impacts are close to zero, whereas the effects become beneficial for participants in the long run; that the type of programme is important, whereas greater benefits are for programmes that emphasize skills, knowledge and experience formation; that impacts are greater for women and participants who entered into employment programmes after being unemployed for more than one year and the effects of employment programme are beneficial for participants more likely in a recession. 
Baumgartner et al. (2008), on the other hand, provide a study of the effects of two employment programmes to encourage self-employment in Germany using matching with difference in differences approach. Baumgartner et al. (2008) conclude that the aforementioned self-employment programmes proved to be effective and that such type of employment programmes may be the one for which the funds are distributed effectively.

Martin (2014) describes trends in spending for active labour market policies in OECD countries and how the economic crisis affected the spending in OECD countries and argues that such spending is seen as very important in enabling unemployed people transition from social benefits to work. Martin (2014) adds that microeconometric evaluation should be complemented with macroeconomic analysis. Macroeconometric evidence of the impact of active labour market policies on unemployment and employment can be found for example in Murtin et al. (2013a); Murtin et al. (2013b); Bassanini et al. (2009); Belot et al. (2004). All studies mentioned estimate the impact of active labour market policies on aggregate labour market and all studies mentioned suggest that active labour market policies do have impact to reduce unemployment and long-term unemployment.

\section{Methodology}

In order to estimate the effects of expenditures for labour market policy on unemployment rate we construct panel regression model. Variables included in our analysis are government expenditures for active and passive labour market policies and unemployment rate. Due to the availability of data panel regression analysis was performed on a sample of 20 EU countries over the 2004-2015 period. Our panel is balanced. EU countries included in the sample were: Austria (AT), Belgium (BE), Czech Republic (CZ), Denmark (DK), Estonia (EE), Finland (FI), France (FR), Germany (DE), Hungary (HU), Ireland (IE), Italy (IT), Luxembourg (LU), Netherlands (NL), Norway (NO), Poland (PL), Portugal (PT), Slovak Republic (SK), Slovenia (SI), Spain (ES), Sweden (SE). Data needed for empirical analysis were obtained from the OECD.Stat Database (2017). The specification of a panel regression function was the following:

$$
\ln U R_{i, t}=\alpha_{0}+\Pi\left[\begin{array}{l}
\ln A L M P_{i, t} \\
\ln P L M P_{i, t}
\end{array}\right]+\Phi\left[\begin{array}{c}
\ln T U D_{i, t} \\
\ln G D P p c_{i, t} \\
\ln L T U R_{i, t}
\end{array}\right]+\varepsilon_{i, t}
$$

UR $\mathrm{R}_{\mathrm{i}, \mathrm{t}}$ denotes rate of unemployment as \% of labour force, ALMP denotes government expenditures for active labour market policies in country $i$ at time $t$. Such expenditures include labour market policy services and measures. They aim to activate the unemployed and to strengthen the transition process into employment as well as to help people at risk of losing the job (Eurostat, 2013), whereas PLMP refers to government expenditures for passive labour market policies which cover financial assistance mostly unemployment benefits (Eurostat, 2013) (both in \% of gross domestic product GDP). As a control variable of labour market situation we included trade union density (TUD) and long-term unemployment rate (LTUR). In order to control for macroeconomic situation we use gross domestic product per capita in USD PPP (GDPpc). Ln is natural logarithm used to reach the greater symmetric distribution of panel regression variables. With $\Pi$ and $\Phi$ we denote vectors of regression coefficients, the association of rate of unemployment measure with explanatory variables and control variables.

We included year dummies (vector $\Psi$ ) in the above regression function which was re-estimated accordingly: 


$$
\ln U R_{i, t}=\alpha_{0}+\Pi\left[\begin{array}{l}
\ln A L M P_{i, t} \\
\ln P L M P_{i, t}
\end{array}\right]+\Phi\left[\begin{array}{c}
\ln T U D_{i, t} \\
\ln G D P p c_{i, t} \\
\ln L T U R_{i, t}
\end{array}\right]+\Psi\left[\begin{array}{c}
\text { Year2004 } \\
\vdots \\
Y \text { ear2015 }
\end{array}\right]+\varepsilon_{i, t}
$$

We introduced fixed and random effects across model specifications in order to try to avoid biases that could arise from different estimation methodologies (see, for example Kennedy, 2008; Stock et al., 2015; Wooldridge, 2010). Robust standard errors were used to control for heteroskedacity and autocorrelation (similar methodological approach can be found in Južnik Rotar, 2017).

\section{Results and discussion}

Table 1 provides descriptive statistics for all the variables included in the empirical study. Table 2 reports correlation coefficients between these variables. Following the recommendations from the literature the multicollinearity may be a problem if the zero-order correlation coefficient of each two regressors is over 0,8 (see, for example Wooldridge, 2010). In our study the correlation coefficients are all in acceptable levels as can be seen in Table 2.

In order to distinguish the effects of expenditures for labour market policies on unemployment rate, we separately analysed the effects of expenditures for active labour market policies and the effects of expenditures for passive labour market policies on unemployment rate. The most obvious aim of labour market policy is to help people back into employment and termination of unemployment. Active labour market programmes include for example public employment services, counselling and administration, programmes for youth targeted in transition from school to work, training programmes which all try to improve the prospects of unemployed person in the labour market gaining skills and knowledge needed in fast changing labour market with human capital accumulation and increased labour productivity. Regarding all this one would expect that the expenditures for active labour market policy would have a negative effect on unemployment rate.

Figure 1 shows the expenditures for active labour market policies and unemployment rate. It can be seen, that the relationship between expenditures for active labour market policies and unemployment rate is negative, suggesting that ALMPs might decrease unemployment rate.

Table 1

Descriptive statistics for panel regression variables

\begin{tabular}{lrrrr}
\hline & Mean & $\begin{array}{l}\text { Standard } \\
\text { deviation }\end{array}$ & Minimum & Maximum \\
\hline InALMP & -0.545 & 0.619 & -2.995 & 0.717 \\
InPLMP & -0.161 & 0.762 & -2.525 & 1.115 \\
InTUD & 3.221 & 0.684 & 1.504 & 4.357 \\
InGDPpC & 10.477 & 0.349 & 9.685 & 11.414 \\
InLTUR & 3.581 & 0.427 & 2.251 & 4.334 \\
InUR & 2.020 & 0.435 & 0.916 & 3.261 \\
\hline
\end{tabular}

Source: Authors' work, OECD database 
Table 2

Correlation matrix for panel regression variables

\begin{tabular}{|c|c|c|c|c|c|}
\hline & InALMP & InPLMP & InTUD & InGDPpC & InLTUR \\
\hline InALMP & 1.000 & 0.699 & 0.470 & 0.480 & -0.472 \\
\hline InPLMP & & 1.000 & 0.296 & 0.314 & -0.103 \\
\hline InTUD & & & 1.000 & 0.559 & -0.565 \\
\hline InGDPpC & & & & 1.000 & -0.543 \\
\hline InLTUR & & & & & 1.000 \\
\hline
\end{tabular}

Source: Authors' work, OECD database

Figure 1

Expenditures for ALMPs (\% of GDP) and rate of unemployment as \% of labour force

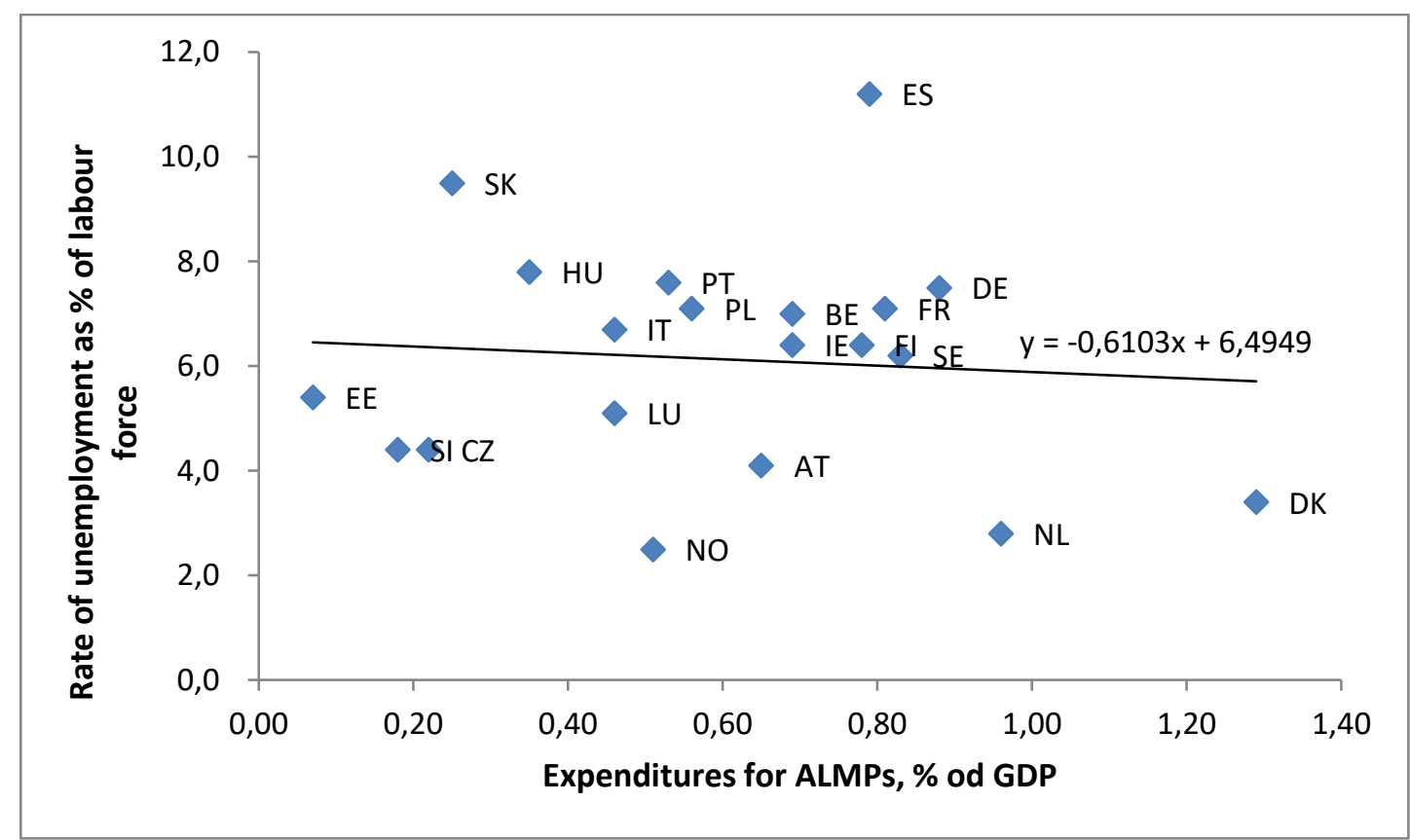

Source: Authors' work, OECD database

According to the methodological explanation taken from Eurostat the expenditures for passive labour market policies which form the group of labour market policy supports include the categories out-of-work income maintenance and support and early retirement. Since the main aim of such policies is to provide financial help to unemployed person it is difficult to straightforward conclude whether such policies have positive or negative effect on labour market outcomes.

The usual critique of such policies is that they only provide money transfer and as such, they do not empower unemployed person to effectively combat against unemployment. The so-called lock in effect may also be present (see, for example Van den Berg et al., 2015). It refers to lowering the motivation of unemployed person to actively search for a job and additionally building their knowledge as with time knowledge becomes obsolete.

Figure 2 depicts the expenditures for passive labour market policies and unemployment rate. Figure 2 shows the positive relationship between expenditures for passive labour market policies and unemployment rate, suggesting that such policies might produce counter effects and increase unemployment. 
Figure 2

Expenditures for PLMPs (\% of GDP) and rate of unemployment as \% of labour force

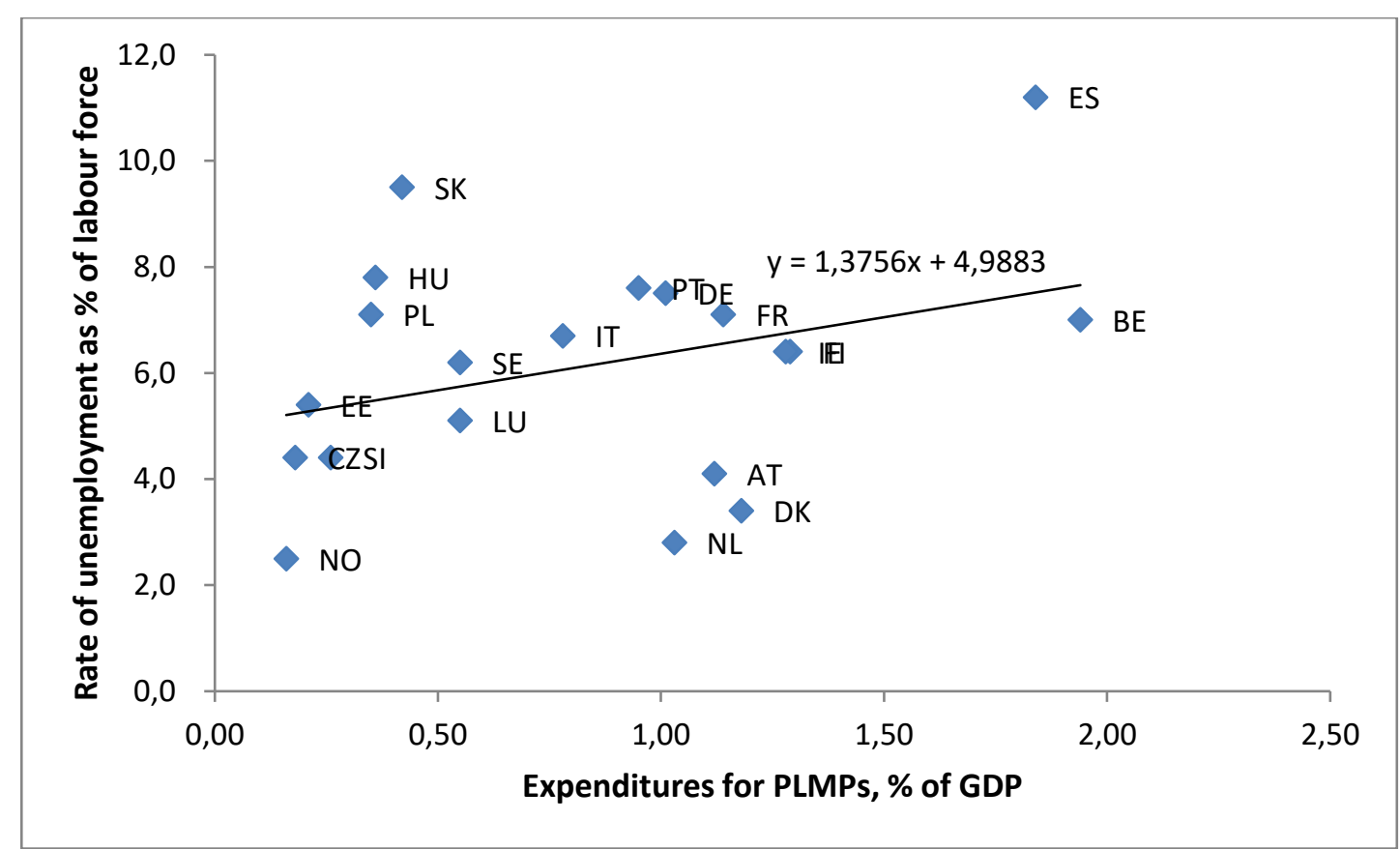

Source: Authors' work, OECD database

In order to quantify the effects of expenditures for labour market policies on unemployment rate we performed panel regression analysis and analysed relationships between unemployment rate and both active and passive labour market policies. The panel data set consisted of 20 EU countries during 2004-2015 period. Table 3 shows the estimation results of the panel regression analysis. The results confirm our hypothesis of the research that the effects of expenditures for active labour market policies are negative on unemployment rate, whereas the effects of expenditures for passive labour market policies are positive on unemployment rate. The results are similar for fixed and random effects. From the panel regression results the expenditures for active labour market policies have negative and statistically significant effect on unemployment rate. On the other hand, the expenditures for passive labour market policies have positive and statistically significant effect on unemployment rate, meaning that higher expenditures for passive labour market policies are statistically significantly connected with higher unemployment rate. In 2008 the EU was hit by the most severe economic crisis with rising unemployment and lowering economic activity. Different European countries differently responded to such situation. In times of high and persistent unemployment different labour market policies are gaining their meaning. Besides that, the potential has been seen in the "revival" of activation strategies to help the unemployed person, especially target groups of unemployed defined by European Commission. Such strategies are based on carrot and stick motivation imposing conditionality requirements, for example, that benefit recipient must actively approach to finding a job. If the benefit recipient does not meet the conditions, a benefit sanction follows. This require strict monitoring of jobseeker behaviour of whether he is actively searching for a job, but also guiding and counselling the unemployed person to effectively match unemployed person with job vacancies. Besides that, passive labour market policies should provide good information to unemployed person about the coordination between tax and benefit system. The transparency of benefit system should be enabled in order that each 
unemployed person would receive unequivocally information that it is better to work (see, for example Južnik Rotar, 2017).

Table 3

Estimation results of panel regression analysis

\begin{tabular}{lrr}
\hline \multicolumn{3}{c}{ Unemployment rate } \\
\hline Model & \multicolumn{1}{c}{ r } & \multicolumn{1}{c}{} \\
Constant & Fixed (within group) effects & $8.755^{*}(0.710)$ \\
InALMP & $8.874^{*}(0.903)$ & $-0.185^{*}(0.047)$ \\
InPLMP & $-0.113^{*}(0.035)$ & $0.326^{*}(0.033)$ \\
InGDPpc & $0.306^{*}(0.027)$ & $-0.734^{*}(0.059)$ \\
InLTUR & $-0.731^{*}(0.074)$ & $0.175^{*}(0.053)$ \\
InTUD & $0.193^{*}(0.056)$ & $0.056(0.036)$ \\
& $0.032(0.020)$ & \\
Constant & Random effects GLS & $8.459^{*}(0.719)$ \\
InALMP & $8.505^{*}(0.835)$ & $-0.153^{*}(0.043)$ \\
InPLMP & $-0.087^{*}(0.033)$ & $0.320^{*}(0.030)$ \\
InGDPpc & $0.303^{*}(0.024)$ & $-0.707^{*}(0.060)$ \\
InLTUR & $-0.701^{*}(0.069)$ & $0.209^{*}(0.049)$ \\
InTUD & $0.228^{*}(0.052)$ & $0.027(0.032)$ \\
Year dummies & $0.013(0.019)$ & Yes \\
Hausman test & No & $75.493^{*}$ \\
No. of obs. & $75.579 *$ & 240 \\
\hline
\end{tabular}

Note: *significant at 1\%; robust standard errors in parentheses

Source: Authors' work, OECD database

\section{Conclusion}

The aim of this paper was to estimate the effects of expenditures for labour market policies on unemployment rate for 20 EU countries including Austria, Belgium, Czech Republic, Denmark, Estonia, Finland, France, Germany, Hungary, Ireland, Italy, Luxembourg, Netherlands, Norway, Poland, Portugal, Slovak Republic, Slovenia, Spain, Sweden over the 2004-2015 period. Estimation results confirmed our hypothesis, which is the effects of expenditures for active labour market policies are negative on unemployment rate, whereas the effects of expenditures for passive labour market policies are positive on unemployment rate, suggesting that expenditures for passive labour market policies are not effectively distributed. Not only the activation strategies with benefit conditioning, but also encouraging and enabling unemployed person to actively approach in searching for a job should be implemented. The implementation of activation strategies should be supported. A clear signal should be passed to unemployed people that the benefits are greater if working than receiving social benefits. The availability of data for longer time period and other European countries is seen as an limitation of this research. Decomposing unemployment rate into different age structure is seen as a possible direction for future research. Especially focusing on youth unemployment rate as youth are usually to the greater extent hit by the periods of economic expansion and recession on the labour market. After all, within the European Union, special attention is devoted to help young people on the labour market and there is a need to sustain the young human capital. 


\section{References}

1. Bassanini, A., Duval. R. (2009), "Unemployment, institutions and reform complementarities: reassessing the aggregate evidence for OECD countries", Oxford Review of Economic Policy, Vol. 25, No. 1, pp. 40-59.

2. Baumgartner, H. J., Caliendo, M. (2008), "Turning unemployment into self-employment: effectiveness of two start-up programmes", Oxford Bulletin of Economics and Statistics, Vol. 70, No. 3, pp. 347-373.

3. Belot, M., Van Ours. J. C. (2004), "Does the recent success of some OECD countries in lowering their unemployment rates lie in the clever design of their labour market reforms?", Oxford Economic Papers, Vol. 56, No. 4, pp. 621-642.

4. Caliendo, M., Schmidl, R. (2015), "Youth unemployment and active labor market policies in Europe", IZA Journal of Labor Policy, Vol. 5, No. 1.

5. Card, D., Kluve, J., Weber, A. (2015), "What works? A meta analysis of recent active labour market program evaluations", NBER working paper, No. 21431, National Bureau of Economic Research, Cambridge, MA, July 2015, revised April 2017.

6. Dehejia, R. H. (2013), "The porous dialectic: experimental and non-experimental methods in development economics", WIDER Working Paper 011.

7. Eurostat (2013). Labour market policy statistics. Methodology 2013, Publications Office of the European Union, Luxembourg.

8. Eurostat (2017), "Eurostat statistics explained. Unemployment statistics", available at: http://ec.europa.eu/eurostat/statistics-explained/index.php/Unemployment_statistics (20 December 2017).

9. Frölich, M., Lechner, M. (2015), "Combining matching and nonparametric instrumental variable estimation: theory and an application to the evaluation of active labour market policies", Journal of Applied Econometrics, Vol. 30 No. 5, pp. 718-738.

10. Gertler, J. P., Martinez, S., Premand, P., Rawlings, L. B., Vermeersch, C. M. J. (2016). Impact Evaluation in Practice, The World Bank, Washington.

11. Gonzalez Carreras, F. J., Kirchner Sala, L., Speckesser, S. (2015),"The effectiveness of policies to combat youth unemployment", STYLE Working Papers, WP3.2. CROME, University of Brighton, Brighton.

12. Hansen, B., Rosenbaum, P. R., Small, D. (2014), "Clustered treatment assignments and sensitivity to unmeasured biases in observational studies", Journal of the American Statistical Association, Vol. 109, No. 505, pp. 133-144.

13. Heckman, J. J., Pinto, R. (2015), "Causal analysis after Haavelmo", Econometric Theory, Vol. 31, No. 1, pp. 115-151.

14. Huber, M., Lechner, M., Wunsch, C. (2013), "The performance of estimators based on the propensity score", Journal of Econometrics, Vol. 175, No. 1, pp. 1-21.

15. Južnik Rotar, L. (2012), "How effective is the Slovenian institutional training program in improving youth's chances of reemployment?", Eastern European Economics, Vol. 50, No. 3, pp. 94-106.

16. Južnik Rotar, L. (2017), "Labour market policy and association with productivity", in Yongqiang, L., Hunjet, A., Roncevic, A. (Eds), Economic and social development, Varazdin Development and Entrepreneurship Agency, Varazdin, Croatia; City of Prague; Faculty of Management University of Warsaw, Warsaw, Poland; University North, Koprivnica, Croatia, pp. 85-91.

17. Kennedy, P. (2008). A guide to econometrics, Wiley-Blackwell Publishing, Malden.

18. Khandker, S. R., Koolwal, G. B., Samad, H. A. (2010). Handbook on Impact Evaluation. Quantitative Methods and Practices, World Bank, Washington.

19. Kluve, J. (2010), "The effectiveness of European active labor market programs", Labour Economics, Vol. 17, No. 6, pp. 904-918.

20. Martin, J. P. (2014). Activation and active labour market policies in OECD countries: stylized facts and evidence on their effectiveness, University College Dublin, Geary Institute, Dublin.

21. Murtin, F., De Serres, A. (2013a), "How do labour market institutions affect the exit rate out of unemployment?", OECD Economics Department Working Papers, OECD Publishing. 
22. Murtin, F., De Serres, A., Hijzen, A. (2013b), "The ins and outs of unemployment", OECD Economics Department Working Papers, OECD Publishing.

23. Rosenbaum, P., Rubin, D. B. (1983), "The central role of propensity score in observational studies for causal effects", Biometrika, Vol. 70, No. 1, pp. 41-55.

24. Stock, J. H., Watson, M. W. (2015). Introduction to econometrics, Pearson, Harlow.

25. Van den Berg, G. J., Van der Klaauw, B. (2015), "Structural empirical evaluation of job search monitoring", IFAU Institute for Evaluation of Labour Market and Education Policy Working Paper 16.

26. Wooldridge, J. M. (2010). Econometric Analysis of Cross-Section and Panel Data, MIT Press, Cambridge.

\section{About the author}

Laura Južnik Rotar is an Assistant Professor of Economics at the Faculty of Business, Management and Informatics Novo mesto, University of Novo Mesto. She received her PhD degree from the Faculty of Economics, University of Ljubljana. She has published in refereed journals, such as Panoeconomicus, Eastern European Economics, Managing Global Transitions, Our Economy, and Management. She has been involved in several research projects on national and European level. The author can be contacted at laura_juznik@yahoo.com. 